Article

\title{
Corporate Social Responsibility, Sustainability, Sustainable Development and Corporate Sustainability: What Is the Difference, and Does It Matter?
}

\author{
Benedict Sheehy ${ }^{1, *}$ and Federica Farneti ${ }^{2}$ (D) \\ 1 Canberra Law School, University of Canberra, Canberra, ACT 2617, Australia \\ 2 Department Sociology and Business Law, University of Bologna, 40125 Bologna, Italy; \\ federica.farneti@unibo.it \\ * Correspondence: benedict.sheehy@canberra.edu.au
}

Citation: Sheehy, B.; Farneti, F. Corporate Social Responsibility, Sustainability, Sustainable Development and Corporate Sustainability: What Is the Difference, and Does It Matter? Sustainability 2021, 13, 5965. https://doi.org/ $10.3390 /$ su13115965

Academic Editor: Jorge Matute

Received: 9 February 2021

Accepted: 14 May 2021

Published: 25 May 2021

Publisher's Note: MDPI stays neutral with regard to jurisdictional claims in published maps and institutional affiliations.

Copyright: (c) 2021 by the authors. Licensee MDPI, Basel, Switzerland. This article is an open access article distributed under the terms and conditions of the Creative Commons Attribution (CC BY) license (https:/ / creativecommons.org/licenses/by/ $4.0 /)$.

\begin{abstract}
The terms "corporate social responsibility" (CSR), "sustainability", "sustainable development" and "corporate sustainability" (CS) are critical terms for developing, analysing and evaluating public and private policy goals. These terms are used to make decisions about investment, policy development, and strategy creation. The terms emerged in different fields of endeavour at different points in time. Accordingly, they have different meanings; however, over time they have come to be used interchangeably mixing up policy agendas, confusing managers, regulators, activists and the public at large. We demonstrate that CSR is the best term for focusing on individual business organisations, "corporate sustainability" is an organisation level environmental policy, "sustainable development" is a public policy, and "sustainability" is the broadest term encompassing global local and organisational levels.
\end{abstract}

Keywords: definitions; corporate social responsibility; corporate sustainability; sustainable development goals; sustainability

\section{Introduction}

The terms Corporate Social Responsibility "CSR" and Corporate Sustainability have become buzzwords in the private sector. Indeed, as van Marrewijk observes, "many consider corporate sustainability and CSR as synonyms" [1] (p. 102). Yet the two terms have distinct meanings and it has become increasingly clear that there is a great need for clarification and related precision. In addition to these private sector terms, in the public sector, the terms "sustainability" and "sustainable development" are used adding further confusion. These four different but related terms give rise to two important questions: first, do the terms mean essentially the same thing? Second, if they have different meanings, is that difference significant (for example setting goals, making decisions, contributing towards different stakeholders, etc.)?

This article answers these two questions using a method drawn from the history of ideas scholars - scholars who aim to understand the social relations of ideas [2] — to identify how each of the terms supports distinct objectives, objectives that are obscured by the current lack of clarity. The focus of our article is how clarity facilitates decision-making in three important areas of activity: (1) governmental and non-governmental policy advocates who, for example, may be pursuing environmental policy, (2) business management decision-makers who, for example, may be looking for methods of cleaner production and improved social interactions and, (3) scholars seeking the advancement of knowledge through academic research by, for example, investigating policies which are most likely to succeed in improving the environmental performance of business organisations (See for example: $[3,4])$. To an important degree in organsiational studies and evaluation, the focal point of these three issues is drawn together by Lawler III and Worley. In their 
2012 article [5], Lawler III and Worley observed that sustainability had become a major issue for business and that the success of an organization, depends not only on financial performance but on the organisation's impact on the natural and social environment. This aspect of organisational activity they referred to as "sustainable effectiveness" [5]. They noted that few firms are designed and managed to perform well on this measure. One way to provide a measure on how organizations perform is to develop a sustainability report. The contents of sustainability reports are designed in a way that different stakeholders (investors, policymakers, not-for-profit organisations/groups, capital markets, civil society, donors, customers, governments, etc.) can appreciate the overall performance of an organization, particularly the impacts. Organisations disclose what they consider the material for the type of activity undertaken. Thus, material topics can be economic, environmental or social ones, or all of them. This somewhat haphazard approach has led to inconsistency in reporting, strategic reporting such as "greenwashing" as well as efforts to create standards.

Clarity on these concepts allows parties to challenge, advocate or align themselves and their resources in support of important economic, political and social decisions. These decisions impact issues of environmental protection, equity, and social policy. Lack of clarity impairs people's ability to address business impacts on the natural and social environments, unethical business behaviours, and the ability to identify and direct preferred courses of action. In sum, accurate use of these terms helps us distinguish between and contribute to three distinct agendas: (1) saving the planet, (2) implementing organisation-based programs [6], and (3) improving societal interactions with businesses.

We are not the first to address this important issue of differentiating these particular terms. In a significant empirical study from 2008, Montiel examined the differences and overlap of word use. Monteil found that with respect to CSR and CS, the words have different conceptual starting points, engaged different methods and pointed to different focal points; however, he noted that they were tending toward convergence-a merging of ideas, or "common future" [7]. This convergence which Montiel identified, we believe, is in error and likely stemming from a weaker theoretical framework for understanding and differentiation the terms. Montiel's work while helpful in providing empirical insight, saw the convergence as a likely and desirable outcome. Indeed, from a normative perspective, we do not disagree with Montiel. Preservation of the planet must be a policy objective of all parties to production—something embraced by the Sustainable Development Goals (SDG) inclusion of business. In terms of prioritising objectives, identifying responsible parties and parties most suited to action, and mapping out a strategy, however, Montiel's analysis fails to provide adequate guidance for advocates, challengers and managers.

Similarly, the masterful work by Bansal and Song [8] on the terms "corporate sustainability" and "corporate responsibility" provides an empirical foundation for the difference, traces the different origins, focal points and methods. They note the early focus of CSR was on society and social issues, often framed as obligations to stakeholders. By way of contrast, they note that early corporate sustainability's focus was on environment management, a concept distinct from the environmental protection discussion related to economic development now sustainable development. They note the responsibility dialogue focused on the firm as a social actor whereas the sustainability discussion understood the firm as nested in other social and natural systems.

Mapping nomological networks, Bansal and Song note that the terms have strongly similar antecedents and outcomes making the present distinction somewhat problematic, at least from a nomological point of view. Of particular significance, they note that the introduction of strategic approaches to the issues of CSR and the environment led to their convergence. Both created strategic opportunities which fit more readily with the dominant neo-classical model of the firm as an economic, profit-focused actor. Bansal and Song mapped out directions for research based on a clear understanding of the empirical, systems-based approach of sustainability and the normative values-based research of CSR.

Bansal and Song's strong contribution, however, did not address issues of scope, whether organisational, national or international — the levels raised in Aguilera, Rupp et al., 
Ganapathi, Williams Aguilera and Rupp [9], nor did their study explore the enduring policy objective, whether environmental, certain hard law rights, or broader soft law, global policy obligations. Finally, their study did not explore the implications for decision-makers. Indeed, Mohrman and Lawler III [10] note the challenge of these different sustainability initiatives at the organizational level and the need to understand the different organizational objectives. These distinctions are important as delimiting the scope and objective allows advocates, challengers and managers to identify and work toward relevant goals and more effectively and strategically focus their limited resources to those goals.

Given our different objective-connecting the terms to the distinct decision-making contexts, policy objectives and scopes-our paper makes its contribution using a method drawn from intellectual history similar to Carroll's highly cited work tracing the evolution of the idea [11]. This method allows us to identify the core ideas concepts from the private sector CSR and corporate sustainability and place them in the larger context of public sector policies of sustainability and sustainable development. After tracing their intellectual provenance and their conceptual frameworks, it provides examples of how the terms apply to specific decision-making in distinct public and private sector organisational and institutional settings.

In their essence, the three terms - CSR, corporate sustainability and sustainabilitycan be distinguished as follows: CSR has evolved into a form of international private business regulation focused on the environmental and social impacts of business [12]. It includes a host of individual and collective rights in addition to guidance on ethical and environmental issues. It has been a bottom-up push focused on business which has led to a response from global policymakers [13-17]. By way of contrast, corporate sustainability is a term that has both strong public orientated and weak private orientated forms. It contains a rather diverse set of ideas, originates from different groups focused on either sustainable development or environmental concerns but both have a focus on business. Finally, although CSR and corporate sustainability both refer to the concept of business ethics, they do so in quite different ways. The third term, sustainability, is a term that describes a broader public global policy agenda, forming a foundation for sustainable development, focused on the maintenance of ecology that allows the human species to flourish.

We argue that the terms CSR and corporate sustainability have been drawn into the broader term sustainability. Aligning these concepts is important. Bebbington and Grey, for example, in an effort to integrate the concepts of sustainability, sustainable development and business state, "at a minimum, the sustainable business is one that leaves the environment no worse off at the end of each accounting period than it was at the beginning" [18]. As we will argue, however, the term sustainability and the related terms CSR and corporate sustainability have expanded to encompass so much as to threaten to lose all meaning. The main other term in this area of scholarship and professional activity that is unnecessarily confused, corporate citizenship, has been addressed by others. See for example $[4,19,20]$.

All of these terms are certainly related. To some degree at least, they all draw attention to non-financial aspects of business operations. Further, they all include an element of concern about the impacts of business on the natural environment. They each address Lawler and Conger's observation [21] that business as usual is inadequate, and that the core of business operations must have a more positive impact on the environment and society. This sustainable effectiveness approach, they have argued requires organizations to be managed in ways that produce positive results with respect to financial, environmental, and social performance. As we will argue, however, they differ in important ways in terms of policy scope and policy objective. We begin our discussion with a graphic representation of our basic conceptualisations of the terms. Figure 1 below provides a conceptual map showing the scope, objective and overlap. 


\section{Sustainability and Business}

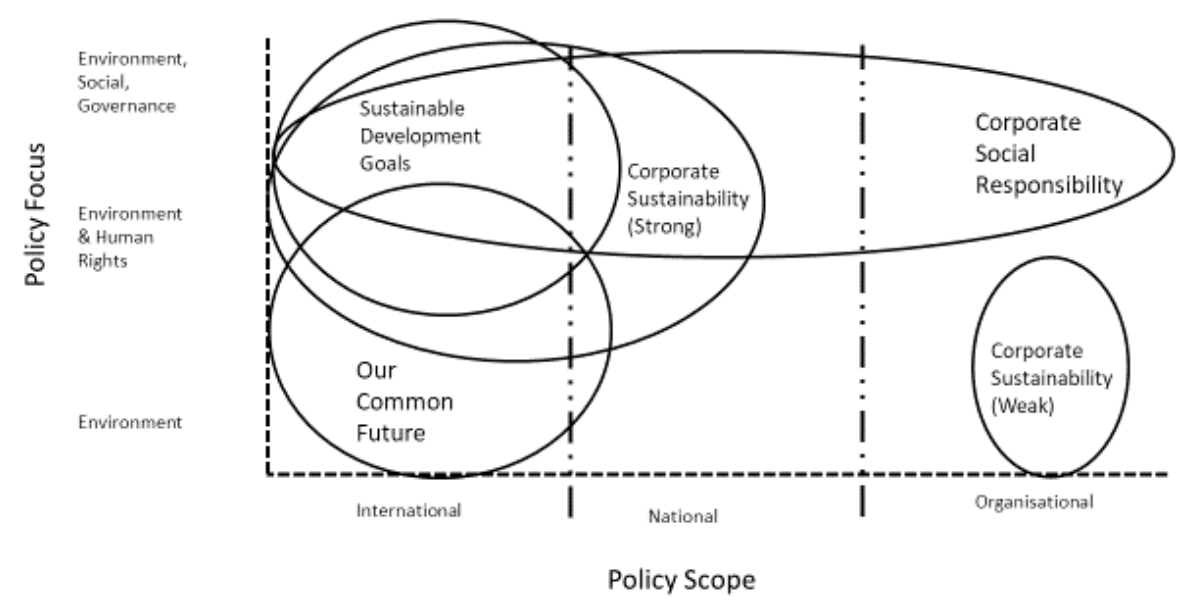

Figure 1. Sustainability and Business.

On the horizontal axis, the scope of the term is illustrated, from international public policy through national to organisational. The broad international scope of the UN's Sustainable Development Goals is readily distinguishable from the narrower scope of CSR on the organisation. The vertical axis represents the range of policy objectives. These range from a sole environmental focus, to a broad, global socio-economic-ecologic agenda.

We turn next to discuss the terms and underlying concepts in detail. To do so, we have divided the article into five sections. The next section identifies. The third and fourth sections deal with CSR and sustainability, sustainable development and corporate sustainability respectively outlining for each of them the policy scope or unit of analysis, and the policy objective. Section 5 answers the question of whether it matters, discusses the relevant ethical discussion and indicates that there is a clear difference. Section 6 explains why the difference is important. A short conclusion follows the review of limitations.

\section{Corporate Social Responsibility}

To understand the critical difference between CSR and the other terms, an understanding of the development of the idea provides a necessary foundation. This historical approach offers insights into its concerns allowing clarification of the difference between terms and ideas.

CSR has been part of the business dialogue for many decades. Its origins are easily traced to the Great Depression debate of Berle and Dodd in a series of Yale Law Review articles. Berle asserted that responsibility could be best understood as "Corporate powers as powers in trust" [22] for shareholders. Dodd replied with "For whom are corporate managers trustees?" [23] arguing that corporate managers were statesmen [sic] to use their powers for the betterment of society [24]. The debate was taken forward through the 1950's with Bowen's classic work, the Social Responsibilities of the Businessman [25] arguing that business needed to think beyond economic management and look carefully at other societal impacts and needs. Davis, writing in the next decade developed what he called the "Iron Law of Responsibility," which held that "social responsibilities of businessmen need to be commensurate with their social power" [26] (p. 71). A range of further developments in the business-and-society discussions expanded the concept and obligation drawing in ever more concerns and parties leading to a vagueness around the term. In fact, CSR had lost clear meaning such that by 1973, Votaw could write: "The term [CSR] is a brilliant one; it means something, but not always the same thing, to everybody. To some it conveys the idea of legal responsibility or liability; to others, it means socially responsible behaviour in an ethical sense; ... many simply equate it with a charitable contribution; ... many of 
those who embrace it most fervently see it as a mere synonym for "legitimacy" ((Votaw 1973) cited in [11]).

In this rapidly developing group of related ideas, Carroll took economist Milton Friedman's idea of responsibility: "conforming to their basic rules of the society, both those embodied in law and those embodied in ethical custom" of a society [27] by identifying the basic rules embodied in ethical custom and provided useful framework: "economic, legal, ethical and discretionary" [28]. His pioneering framework for categorising and prioritising values and obligations can be seen in Figure 2 below. Managers were able to sort through competing claims and agendas to make decisions using Carroll's framework. It helped them considering and evaluate CSR claims and it was useful for scholars and others trying to analyse business-society relations generally.

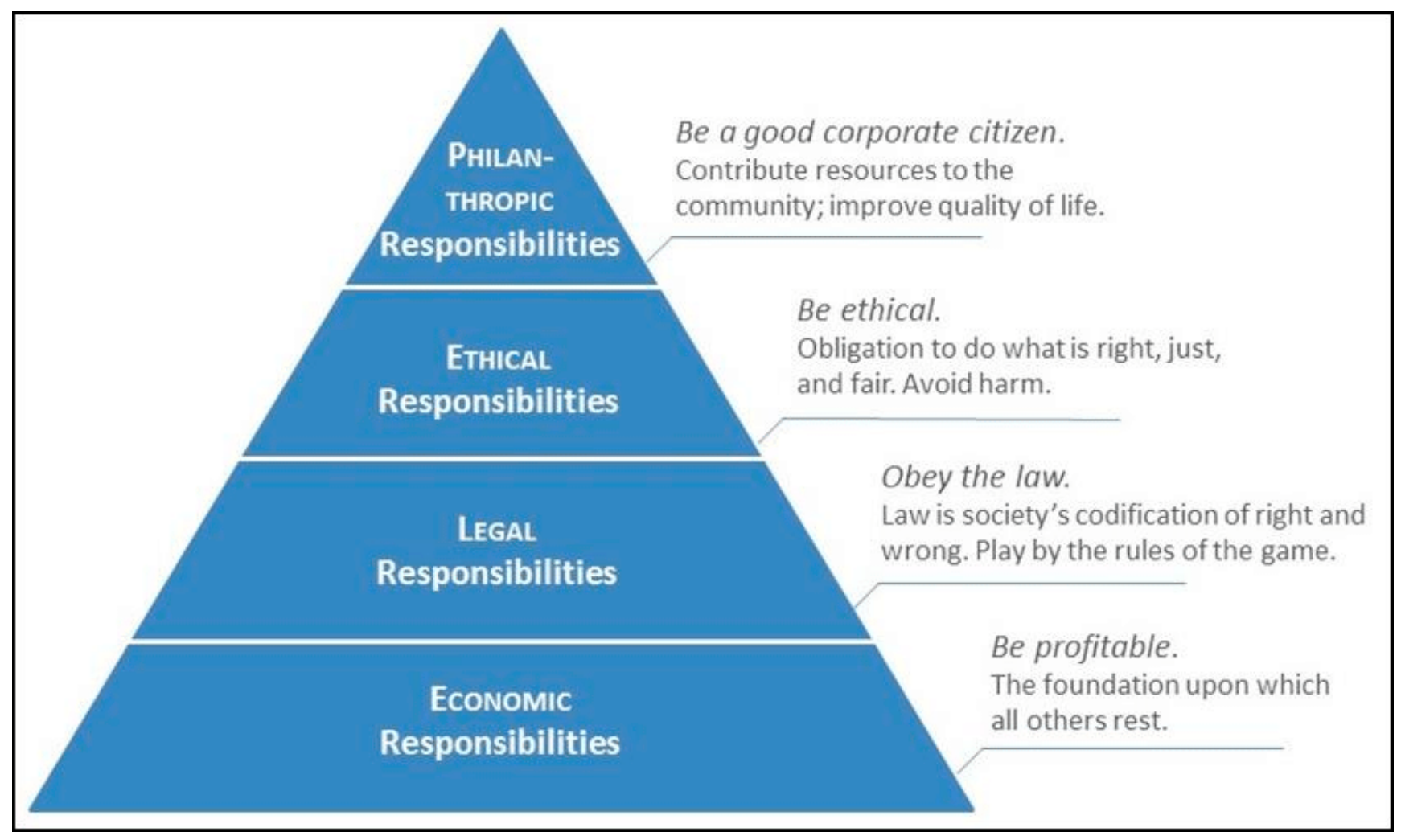

Figure 2. Carroll's Pyramid.

Carroll proposed dividing CSR into four tiers of responsibilities which were ordered according to priority from bottom to top for socially responsible behaviour or activity. His categories of activity ascended from the foundations of economic obligation, to legal, through ethical to philanthropic obligations at the apex. Basically, Carroll argued that a firm has to be financially viable as a first responsibility or it could not exist at all and make no further contribution. Accordingly, the first responsibility of the executive and the foundation of social responsibility is solid economic performance. The second tier of obligation is an obligation to comply with the law. The firm had a responsibility to follow the rules society has set out for all actors-human, state and organisations including business. The third level of obligation is ethical. Once executives had fulfilled economic and legal responsibilities, they could turn their attention to fulfilling the ethical mandate. This level of obligation, argued Carroll, held both a negative prohibition against harm and a positive justice mandate, to treat other parties fairly. The final level of responsibility is philanthropic. Once the executive had achieved the other three objectives, it could turn its attention to philanthropic endeavours. In other words, much like a human individual's 
priorities-sustenance, compliance, care and generosity—a business could have a mirroring or parallel set of priorities or responsibilities.

Carroll has taken a pragmatic approach to the problem. Without some form of revenue or assets, there is little else an organisation can do. Placing his work within the CSR tradition, it sits within a broader ethical tradition, firm-focused and socially engaged. As Bansal and Song note, it is a tradition that draws on North American concerns about socialism and protestant Christianity [8] —although there are arguably earlier roots in the UK [16]. A recent bibliometric study of the term by Meseguer-Sánchez, V., et al., [29] found that CSR "not only represents an aspiration of a good image or profit optimization but also a transparent style of resource management that guarantees results (economic, political, social, environmental, among others) expected, following the economic principle of mutual benefit, the legal principle of respect for the rights of others (individual and collective), and the ethical principle of preservation of non-renewable natural resources, the heritage of future generations."

This discussion of CSR, however, would be incomplete if it were to discuss exclusively its advocates. CSR has also had considerable opposition. Indeed, a famous opponent (or at least apparent opponent), Milton Friedman, made clear his opposition in the title of his oft-cited article, "The social responsibility of business is to increase its profits" [27]. Friedman was arguing particularly against the "statesman" model of CSR noted above. He did not believe it was for a business to take up the role of government in providing public goods. That behaviour, he said, was a misunderstanding of the institutional role of business and led to a misuse of corporate funds. Where Friedman agrees with many contemporary CSR advocates, however, and a position much overlooked in the intervening decades, is his qualifying condition mentioned above: he added that increasing profits may only be done "while conforming to the basic rules of the society, both those embodied in law and those embodied in ethical custom" [27]. This second part of his view has become much of the emphasis and focus of CSR discussion in the intervening years.

Since Friedman's time, society has changed as neo-classical economics has taken hold of the public imagination resulting in a shift in government from the welfare to the regulatory state [30]. These developments have pushed a greater differentiation between public government and private business with an emphasis on the role of business as a private effort tasked with wealth creation and with the government withdrawing from the delivery of goods and services settling instead on the making of the rules for society [31]. To some extent, these changes drove other parts of civil society to organise and put pressure on businesses to regulate their own behaviour in a more responsible way [16,32]. In the 2000's, the global policy agenda had caught up with these national and regional political changes such that international bodies were in a position to begin organising an international response to the reconfigured business-society relationship. The key body formed for this task was the United Nations' Global Compact [15]. The UNGC was created as a set of principles drawing from a wide range of international law instruments and applied them specifically to the business-society interface [15].

This review of the history of CSR provides a critical differentiator between CSR and Corporate Sustainability: CSR is a bottom-up, organisation-driven idea whereas we will argue, (strong) Corporate Sustainability is a top-down, global policy agenda. CSR has developed slowly, incrementally at a thousand different sites for many decades, along the entire 20th century, creating a plurality of definitions $[8,12]$.

Adopting Sheehy's epistemologically developed definition of CSR as: "international private business self-regulation" [12] is useful. Sheehy's definition moves the debate beyond the consensus-based efforts to define the term and beyond descriptive approaches (both of which fail to provide clear, uncontested definitions and criteria). He develops his definition by identifying the nature of CSR, its related obligations and the source of those obligations. Sheehy's analysis places CSR as an international soft law, a global level policy resting on a foundation of international, uncontested norms. This foundation and location, as we shall see, is markedly different from corporate sustainability. 
Following Sheehy's definition, CSR is based on international norms and directed at business organisations. The policy objective is on environmental and social aspects (externalities) both positive and negative. CSR is a regulatory effort and may include a business strategy. It is the expression of a socio-political movement aimed at re-shaping norms of society-business relations. These norms encompass ethical, social and environmental impacts and are increasingly viewed as "de facto law" or transnational law [33]. In other words, Sheehy's definition identifies a global trend in CSR, that is, a trend toward broad, code-based norms - sets of principles and rules which are applicable to all organisations [34,35], or in Friedman's words, creating an obligation to "conform ... to the basic rules of the society, both those embodied in law and those embodied in ethical custom" [27]. This understanding of CSR is, as we argue, quite unlike sustainability and its variants.

The practical implications of this understanding of CSR are the following. In terms of decision-making, clarity of the concept of Corporate Social Responsibility facilitates a clear focus on organisational policy and behaviour. It may include attention to social, employee and other stakeholders, and environmental issues. Further, it is expected that in terms of policy objectives, CSR will have reference to international norms and standards. Accordingly, policymakers, managers and advocates concerned about the behaviours of business organisations, will strengthen their work using CSR frameworks.

\section{Sustainability, Sustainable Development and Corporate Sustainability}

It is well recognised that the term sustainability is problematic. Indeed, the title of White's article "Sustainability: I know it when I see it", is a play on a much earlier court judgment where the court was trying to determine whether a publication was pornographic. White's title highlights the subjective, ill-defined nature of the concept of sustainability as it currently stands [36].

There has been a range of efforts to define the term. In his analysis of the concept of sustainability, Lozano helpfully identifies five main lenses. These are: economic, non-degradation, integrational (integrating economic, environmental and social), intergenerational and holistic (essentially encompassing the prior four) [37]. What we can draw from Lozano's analysis is that sustainability is a broad topic and hosts a wide group of views and agendas. Beyond the basic term "sustainability" are a set of related words including environmentalism, sustainable development, corporate sustainability and CSR. This set of concepts may be best understood as occupying one point on the canvas of ideas along the objectives axis which moves from environmentalism through to broad global development goals in Figure 1 above.

We turn next to discuss the terms sustainability, sustainable development and corporate sustainability in some depth to provide a more comprehensive understanding of each of them and to distinguish them adequately from CSR.

\subsection{Sustainability}

Sustainability as a social movement is a global environmental (ecosystem) movement which, depending on how one identifies it, finds its contemporary roots in books such as Meadow's et al.'s The Limits to Growth, published in 1972 [38] and Rachel Carson's earlier work, Silent Spring [39] or as discussed below, in the subsequent UN ecology initiative. Meadow et al.'s book argued that the industrial model of production was leading to irreparable harm to the ecosystem, essentially the same argument Carson popularised through her fictional account.

The ecological view has been described by Marshall thus: "Originally framed in terms of famine and overpopulation, much of the debate has turned to the function of ecosystems and the consumption of natural resources" [40]. The two core areas of focus in sustainability may be summarised as the capacity of the natural environment to sustain human life and the impacts of human industrial activity on the natural environment most of which are detrimental. In their widely cited review of the concept, Marshall and Toffel identify four levels of sustainability: human survival, human health, human rights and ethics. They 
provide a useful graphic representation of these sustainability concepts in the form of a hierarchy, Figure 3 below [40].

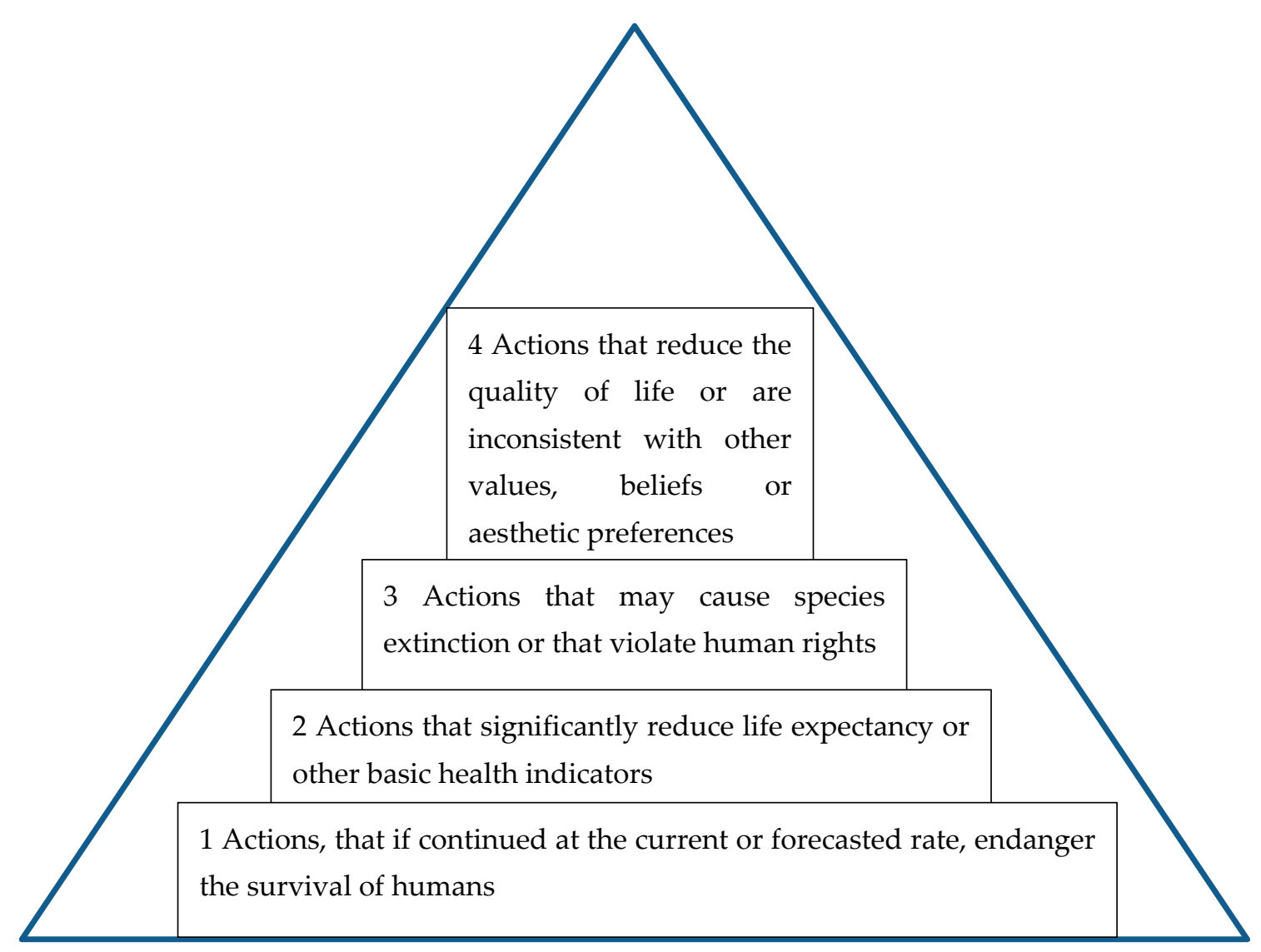

Figure 3. Hierarchy, reproduced from Marshall and Toffel, p. 675.

In discussing their hierarchy of sustainability, Marshal and Toffel explicitly argue against including an ethical level in the concept of sustainability. This position aligns with Bansal and Song's empirical analysis which places sustainability among the natural sciences [8]. Marshal and Toffel explain their reasoning as follows: "We believe that sustainability should not encompass level 4 [ethical] issues. The concept of sustainability has become too broad, largely due to attempts to incorporate too many diverse views and opinions about desirable policy objectives" [40].

To the extent that sustainability ought to include business, they have this to offer:

"Implications for Companies. Common usage of the term sustainability implies a wide variety of units of analysis: societies, technologies, corporations, buildings, and industrial processes. Despite efforts to define a "sustainable organization" and the recent emergence of "sustainability management systems", some argue that "individual organizations cannot become sustainable: individual organizations simply contribute to the large system in which sustainability may or may not be achieved". We posit an intermediate view by claiming that organizations are an inappropriate unit of analysis for some sustainability hierarchy levels but appropriate for others."

Thus, Marshal and Toffel offer two critical starting points for our consideration of sustainability and business. First, they make it clear that ethical matters should be excluded from the term. Ethics is about matters too diverse and contested whereas sustainability, focused on the relationship between the ecology and the human species is sufficiently complex and compelling in its own right. Ethics is a normative, values-based concern whereas sustainability is a matter of empirical sciences. Secondly, they emphasise the fundamental problem of making organisations the unit of analysis. Organisation are 
too small and simply part of the larger systems that make up the ecology. They add a third implicit issue. The issue of sustainability is a global matter, which while including organisations, cannot be limited to them. In sum, Marshal and Toffell see sustainability as fundamentally ecological. This view aligns with Kuhlman and Farrington who see the importance of keeping the term 'sustainability' focused on ecological concerns [41].

Their view aligns with Bansal and Song as well as Lozano's view. Bansal and Song identify natural science methods with systems thinking as being the foundation of sustainability [8]. Lozano notes in his analysis that the majority of authors "seldom consider the importance of social aspects" [37] (p. 1838). In other words, while sustainability is primarily ecologically focused and may have an economic element, it is systems-focused. Thus, when considering sustainability, the unit of analysis is represented by the global ecosystem; the method is a natural science, the actors are international public organisations and nation-states and finally, the objective concerns environmental matters.

The analysis of the term indicates that sustainability is a broad public policy. It is further primarily focused on ecology. As a policy, it does not engage hard law at the national level, but does engage soft law at the international level. As such, Banon Gomis' view [42], that sustainability is better understood as a guide to ethical decision-making: "a moral way of acting ... in which the person or group intends to avoid deleterious effects on the environmental, social, and economic domains, and which is consistent with a harmonious relationship with those domains that is conducive to a flourishing life." [42] (p. 176).

To the extent that business chooses to engage with it, business does so on its own initiative. The practical implications of this understanding are as follows. In terms of decision-making, when policymakers, managers and advocates are working on ecological issues, such as matters that may impact the natural environment up to and including consideration of the boundaries of the planet, the better term is "sustainability". Including additional language or referring to the "corporation" or "ethics", is likely to misdirect the debate and so wastes time, attention and resources.

We turn next to the related term and concept, "sustainable development" which is often conflated with sustainability.

\subsection{Sustainable Development}

As Baumgartner and Rauter observe: "A plethora of related guidelines and definitions have emerged. In order for the concept [of sustainable development] to become more binding, concrete and actionable, participation is required from numerous actors at various levels of society" [43]. Realizing the need to focus on specific actors, their work is on industrial organisations. The larger work, however, identifying which actors should be undertaking what activities, is critical, and makes understanding the terms easier.

The use of the term sustainability as used in the sustainable development dialogue has spread widely and creates significant confusion elsewhere. Building on the foundation of social concern generated by the books of Meadows et al. and Carson mentioned earlier and the subsequent environmental movement, it started a movement that morphed into the sustainability movement, which began as an effort to raise global awareness of the problems and subsequently developed into a global policy agenda. That agenda was captured and consolidated in the UN's report "Our Common Future" [44].

The common understanding of sustainability is drawn directly from the report: "[to] that meets the needs of the present without compromising the ability of future generations to meet their own needs." [44] (p. 37). This common understanding, however, is in fact a misunderstanding and misrepresentation of the term "sustainability." The report connects the term sustainability directly with development. The whole quotation and hence proper definition is: "Sustainable development is development that meets the needs of the present without compromising the ability of future generations to meet their own needs." It is important to observe that in this iteration, the focus was on development- the goal being that further development be done in such a way that the environment is not excessively compromised in the process. Thus, the Bruntland Report, as it is more commonly known, 
is focused on development. Central to sustainable development is the aim of increasing the per capita income and wealth without leaving present or future generations worse off [45] (p. 174). To address the Brundtland Report, governments have responded by embracing sustainable development policy as national policy frameworks and developed related goals [46].

The Brundtland Report was used to form the foundation for the UN's Millennium Development Goals (MDG's). The MDG's set the development agenda for the period 2000-2015 while their successor, the Sustainable Development Goals (SDG's), formally launched in 2015 set the agenda for the next 15 year period. These documents are both toplevel policy instruments that establish a policy pathway for the $\mathrm{UN}$ and other organisations and states working toward these goals or otherwise involved with development [47,48]. Moving beyond the simpler or more basic focus of the MDG's, the SDG's have a global goal of changing how societies organise and operate, including business, to save the planet from human destruction and to allow the human species to survive.

As is evident from the Brundtland Report and the UN's broader history, economic development is an important UN policy initiative. These contemporary initiatives aim to help improve governance across the globe in a way that sustains both the ecological systems of nature and the social systems of humanity. The SDGs include an economic development component: Goal 8 "Decent Work and Economic Growth". This goal includes targets such as "sustaining per capita economic growth ... Higher levels of economic productivity ... full and productive employment ... reduc[ing] the proportion of youth not in employment ... strengthen[ing] the capacity of domestic financial institutions" (United Nations Division for Sustainable Development Goals nd) np. Sustainable development has long had a connection to CSR for a variety of moral reasons, particularly as is commonly noted that ability to command significant resources in communities where resources are scarce to begin with [49]. The SDGs', as noted, are a policy agenda for all people and organisations worldwide. The SDGs are considered the "most salient point of departure for understanding and achieving environmental and human development ambitions up to (and no doubt beyond) the year 2030" [50] (p. 2). Indeed, where organisations have committed to certain SDG's specific, measurable outcomes are evident. Gallego-Sosa [51] have examined the degree of CSR, using a sample of the 30 largest banks in Europe in terms of market capitalization, found that these banks target at least one of the SDGs and that the banks that are most committed to Goals 11 (Sustainable Cities and Communities) and 13 (Climate Action) of the 2030 Agenda have greater gender diversity on their boards of directors. Again, Sprinks [52] et al. (2021) demonstrate greater confidence among people associated with business organisations the projects of which are readily related to the SDGs.

The core message in all of the sustainable development policy documents and literature is that while sustainability is environmentally focused, sustainable development contains the concept of economic sustainability. Further, in this context, economic sustainability-i.e., making a profit-is considered normatively as equivalent to ecological sustainability, saving ecosystems. In other words, the sustainable development agenda so construed lets the ecology be ignored to make a profit and still allow an organisation to make a defensible claim to contributing to sustainability, or at least, sustainable development.

The economic focus of the SDG's has been taken up widely among businesses. For example, a survey conducted by PWC in 2015 indicated that $71 \%$ of businesses said they were already planning how they would engage with the SDGs [53] (p. 8). Thus, the term sustainability, through its connection with sustainable development, has come to include a strong focus on economic development, the opening of new markets and new opportunities for global finance.

To summarise, sustainable development is global or international in scope and comprehensive in terms of objective. It is a globally driven, top-down, public policy initiative-as noted, markedly different from CSR's bottom-up, private, organisationally driven origins. Its scope is primarily public international bodies and nation-states with multinational enterprises involved through initiatives such as the United Nations Global Compact. It is 
focused on public international development policy encompassing initially environmental goals but expanding to include social and economic goals. Accordingly, policymakers, managers and advocates concerned about the behaviours of business organisations in relation to these high-level development goals, appropriately discuss their concerns using the language of sustainability and sustainable development. The objective is global economic and social development and doing so within planetary boundaries. We turn to analyse the term corporate sustainability next.

\subsection{Corporate Sustainability and Corporate Environmentalism}

To the extent that Corporate Sustainability is a unified concept, it is a markedly different than either sustainability or CSR. Essentially, corporate sustainability is a view that companies and their directors have a responsibility beyond profit, [54] (p. 325)-a position that correctly expresses corporate law in major Anglo-American jurisdictions [55]. As Sjafjel et al. note, there are "weak" and "strong" versions of corporate sustainability. Weak corporate sustainability, they observe, focuses on "internalising environmental and social impacts ... but only to the degree that this has a positive effect on long-term financial performance" [56] (p. 4). This approach can be seen in the oil and gas industry. Ruban and Yashalova [57] focus on major oil and gas corporations. In their analysis of the values publicly posted by 25 hydrocarbon organisations on their web-pages they found that social values are publicized by $48 \%$ of the organisations, and environmental values are identified by $40 \%$ of the companies. While social values are rather detailed, environmental values are generic. Further, they found that in the overall publicly facing websites, societal and environmental interests are underrepresented among the values of the major hydrocarbon corporations [57].

Strong corporate sustainability, by way of contrast, includes legal and governance structures that recognise planetary limits, the boundaries of the ecology and as such is unlike economics which adopts models with unlimited natural boundaries. Further, they argue that strong corporate sustainability includes human rights and addresses social needs.

The focus of the analysis that follows is on the historically widespread weak corporate sustainability. Corporate sustainability finds its roots in two areas of social activity [7] (p. 254). The first is the broader environmentally-focused dialogue about global environmental sustainability and sustainable development discussed above [46]. The second is a niche of business-and-society concern denominated "corporate environmentalism" [58]. The latter concern arose in the 1970 's to address a range of environmental disasters that captured public attention [36]. As Hoffman explains it, corporate environmentalism has experienced an "evolution in what environmentalism "means" to the corporation-how it is conceptualized and what is seen as the proper role and response of the corporation in responding to it" [58]. Importantly, Hoffman goes on to state: "This meaning is not for the corporation alone to decide" [58]. In other words, there are parties external to the corporation whose views are to be included in the decision: business interests are not to triumph over all of civil society's interests (See discussion in [12]. Corporate environmentalism, however, like sustainability in the first instance, ignored matters of social concern with an exclusive focus on environmental impacts.

To understand contemporary usage, Dyllick and Hockert's broadly accepted definition of "corporate sustainability" is most useful. They define corporate sustainability as "meeting the needs of a firm's direct and indirect stakeholders (such as shareholders, employees, clients, pressure groups, communities, etc.), without compromising its ability to meet the needs of future stakeholders as well" [59]. The scope considered in this definition, clearly adapted from sustainable development, is limited to the organisation. The concern is the firm's stakeholders, those directly able to affect its operations, finance or market. The definition has no mention of ethics. There is no explicit mention of the environment-although some others such Hahn and Figge state that "there seems to be some implicit pragmatic consensus that corporate sustainability refers to some composite 
and multi-faceted construct that entails environmental, social, and economic organizational outcomes" [54] (p. 327). Finally, it is worthwhile noting that the intergenerational aspect of sustainability is limited to the next set of stakeholders. It is fundamentally an organisationally focused concept with a finance emphasis.

Recent work by Amini and Bienstock, has tried to consolidate and operationalise the discussion [60]. In their well-developed piece, which acknowledges the complexity and far-reaching aspects of sustainability, they confirm the term corporate sustainability as organisationally specific in terms of scope and its primary objective as ecological. While Amini and Bienstock add innovation as a further dimension, the policy objective is the strategic profit potential of corporate sustainability. A slightly different development of the term comes from [61] who define corporate sustainability "as being about individual companies implementing strategies to achieve sustainable development" [61].

As noted at the outset, there is a growing group of scholars advocating the strong version of corporate sustainability. These scholars see the term as a critical starting point and platform for advocating the reform of the configuration of industrial production worldwide. These scholars begin their analysis with the limitations of the earth's ecosystems and then work down to the level of industrial production and argue that for ecological sustainability reasons, businesses must change their fundamental methods of production and that ultimately society too must change its relationship with the environment [62]. Undoubtedly, they are correct in their argument. They use the term sustainability appropriately as an expression of the top-down, global policy in the business sector of the economy; however, this use of the term remain is less common than the weaker version.

Perhaps the main thrust of corporate sustainability, like corporate environmentalism, is the view that ecological sustainability will not be achieved without involving the private [54] (p. 327), public and not for profit sectors [63] — and we would add the underlying culture of consumerism normatively advocated by neo-classical economics. Corporate sustainability in its more common weak version is limited in scope to the organisation, and provides little attention to ethics. In terms of policy objective, it more modest in goals than either CSR or strong corporate sustainability, merely aiming to modify the operations of individual organisations, focusing on value creation [1] (p. 102).

In terms of decision-making, the more common weak corporate sustainability is an organisational level environmental policy. It may be that as the SDGs with their social goals continue to be publicised, the stronger version of corporate sustainability may become more common; however, for the moment, it is the weaker concept that rules. Accordingly, policy makers, managers and advocates concerned about environmental impacts of business organisations, will strengthen their work using the term corporate sustainability.

Further, it possible to argue that, in terms of what should exist in corporate sustainability reports/strategies offered by many companies, sustainability reports in major corporations, such as public-interest entities, are very developed. In continents and countries of the word, like Europe, corporations are obliged by the European Directive 2014/95/EU to disclose in this regard [64]. International dissatisfaction with corporate scandals and the related mistrust lead the EU to introduce a non-financial reporting and disclosure requirement. This is very important as accounting can play a relevant role to support organisations to address SD challenges [64]. However, evidence about the effect of mandatory nonfinancial disclosure on sustainability reporting quality is, at least, controversial. In this regard, Mion et al. [65] developed an analysis to understand if obligatoriness affects such quality and if it causes changes in reporting practices such as harmonizing reports of different countries. Their analysis suggests that obligatoriness improves reporting quality and, fostering the adoption of international guidelines, and introducing some content, such as materiality analysis and quantitative measures of social and environmental performance. To a certain degree, these inconsistencies draw attention to a need to rethink and reform corporate law. 


\section{What Is the Difference?}

As noted, CSR may be best conceptualised as international private business selfregulation [12,35], a type of transnational law [66], and an application of the broad SGD's in the narrower context of business. By way of contrast, corporate sustainability is an effort of an environmentally motivated group to include environmental concerns in industrial operations and an effort within business organisations to capitalise on global policy discussion for improving reputation and efficiencies from environmental initiatives as well as focusing on economic success.

The terms sustainability and sustainable development too are clearly distinct. Marshall and Toffel's thoughtful and critical approach to sustainability and its objectives are markedly distinct from CSR and from corporate sustainability. In Marshall and Toffel's view, sustainability is simply a production and consumption-based directive aimed at preserving the ecology. Sustainable development, as we have argued, is an international public policy initiative. It has no direct bearing on business, except for those businesses directly involved in providing goods and services to such development.

Returning to Figure 1 "Sustainability and Business", we can see that in terms of scope and objective, the term "corporate sustainability" is an organisational policy. As such, it fails to address ecological problems which are fundamentally systemic in nature [16]. In terms of objective, it is focused on environmental issues, lacking the ethical element of sustainability. The problems of the environment, of opaque supply chains engaged in all types of questionable practices, of harmful production processes and dangerous products extend well beyond the boundaries of individual business organisations [3]. These issues are not addressed by weak corporate sustainability.

If corporate sustainability is to be understood as not extending to include ethics either in relation to other stakeholders within or external to the firm, nor including the ethical foundations and international law instruments that underpin CSR [12] it is clearly a subordinate concept. CSR is about regulating corporate behaviour ranging in scope from the international soft law and policy level to the individual organisational private policy context. Strong corporate sustainability may be seen as an effort to implement international $\mathrm{UN}$ development policy as a policy framework. While it is useful, it is arguably less so than CSR in addressing the whole range of organisational activities.

One critical difference between the terms CSR and sustainability that garners little attention is that, unlike the broad term sustainability which can be applied to nearly every actor, activity or thing, CSR can only be applied to business organisations $[3,12]$. CSR is a category of responsibility-moral and legal. It identifies a specific duty bearer, an actor who bears responsibility. Further, unlike sustainability, CSR refers exclusively to activities conducted by business organisations and is focused on things resulting from their operations. By way of contrast, the term sustainability may operate solely as a description without implying any obligation. Indeed, hypothetically any organization, activity or thing can be categorised as sustainable or unsustainable. While the term sustainability may be helpful for grouping activities, approaches or actors together, it does not provide nearly enough specificity to assist in discussions focused on businesses and their operations.

Finally, CSR has inherent limitations. It is constrained by the profit motive in business terms, and to a lesser degree by law [30]. While as an organisational policy based on international norms it has an important contribution to the global sustainability agenda, it in no way provides a substitute for the role of government and non-business-focused organisations and NGOs [67].

\section{Does It Matter?}

Allowing a general term like "sustainability" or a more specific term like "corporate sustainability" to replace the much more specific term CSR matters greatly. Using the term corporate sustainability readily excludes attention to other types of unethical, irresponsible business practices from accepting slavery in production to perpetrating fraud on the consumer. It allows businesses to focus on cost-saving environmental initiatives without 
modifying behaviours that attract international censure if those are not of concern to its management. Alternatively, a clear understanding of the terms further prevents businesses from burnishing their credentials as if they were contributing to the resolution of many of the planet's most dire problems. In the same way, the use of the general term sustainability allows business to mask behaviours of great concern-the generation of enormous social costs [68]. These social costs, including ethical issues and cannot simply be ignored and pushed aside.

Businesses are concerned about these issues. Ceesay et al. [69] found that at least $60 \%$ of organisations in the FTSE 100 Index have undertaken social responsibility activities, for example charitable giving, waste reduction initiatives, emissions reduction policy. They need to understand the difference in order to manage them effectively and credibly. For example, environmental policy is not a one-way correlation and needs no management attention. As Shim et al. [70] have found, the association between CSR and the value to specific organisations employing triple bottom line theory is mixed. They found that economic CSR enhanced firm value (in this case restaurants), whereas environmental CSR diminished the value. Businesses need to understand how these different agendas are important and drive their investments-i.e., to aim for Lawler III and Worley's sustainability effectiveness. To that end, businesses need to report on corporate social responsibility. Such a report, often denominated "Sustainability Report" should include social and environmental impacts of the business organization, be referenced to international standards, and benchmarked against industry standards.

Governments too need to understand what is being done inside businesses and have a role in setting reporting standards, to ensure that what is being communicated to the public is accurate. Palea (2018) makes clear that in the EU, for example, an overall public awareness of the role of public policies in aligning the real economy to sustainable development outcomes, this understanding is far from global. The appropriate use of the terms is foundational to holding businesses accountable and advancing appropriate policy solutions.

Similar to Bansal and Song [8] and Montiel [7], in analysing CSR and CS definitions, we have limited our analysis to scholarly work. We have not taken account of colloquial usage. While we have done so for appropriate scholarly purposes—our task as scholars is to bring analytical precision to terms-we acknowledge that colloquial use is significant in both shaping meaning and defining activity. Further, as our aim is not to provide a comprehensive content analysis, our method is not a typical empirical study and we leave it to others who have done exemplary work in the field (See reviews in $[7,8]$ ).

\section{Conclusions}

The aim of this paper has been to distinguish between the terms corporate social responsibility, corporate sustainability, sustainability and sustainable development. By examining their intellectual history and identifying their distinct policy objectives and policy scope, we believe that their differences have become clearer and so are more useful. Although the terms have areas of overlap, failing to adequately distinguish them constitutes a barrier to improving and regulating business behaviour of concern around the globe. Further, the analysis strengthens people's and parties' ability to advocate and defend policy objectives to which they are committed. By analysing the concepts and identifying the distinctions, we aim to contribute to supporting governmental and non-governmental policy advocates, business management and the advancement of knowledge through academic research.

Finally, there remains considerable and significant debate about all of the terms discussed in this study. The aim of this study is not to silence the debate or to have the last word; rather, it is to add precision to this important area of work and provide a foundation for further discussion and debate not simply about the words themselves, but about the underlying concepts and all-important societal decisions and actions about them-the domain of politics. 
Author Contributions: For research articles with several authors, a short paragraph specifying their individual contributions must be provided. B.S.: Contributed initial conceptualization, methodology and drafting. F.F.: Contributed to the literature review, further development of the conceptualization and drafting. Both authors have read and agreed to the published version of the manuscript.

Funding: This research received no external funding.

Acknowledgments: In this section, you can acknowledge any support given which is not covered by the author contribution or funding sections. This may include administrative and technical support, or donations in kind (e.g., materials used for experiments).

Conflicts of Interest: The authors declare no conflict of interest.

\section{References}

1. Van Marrewijk, M. Concepts and Definitions of CSR and Corporate Sustainability: Between Agency and Communion. J. Bus. Ethics 2003, 44, 95-105. [CrossRef]

2. Krieger, M.H. What's Wrong with Plastic Trees?: Rationales for preserving rare natural environments involve economic, societal, and political factors. Science 1973, 179, 446-455. [CrossRef] [PubMed]

3. Rahdari, A.; Rostamy, A. Designing a general set of sustainability indicators at the corporate level. J. Clean. Prod. 2015, 108, 757-771. [CrossRef]

4. Rahdari, A.; Sepasi, S.; Moradi, M. Achieving sustainability through Schumpeterian social entrepreneurship: The role of social enterprises. J. Clean. Prod. 2016, 137, 347-360. [CrossRef]

5. Lawler, E.E., III; Worley, C.G. Designing organizations for sustainable effectiveness. Organ. Dyn. 2012, 41, 265-270. [CrossRef]

6. Bui, B.; de Villiers, C. Carbon emissions management control systems: Field study evidence. J. Clean. Prod. 2017, 166, 1283-1294. [CrossRef]

7. Montiel, I. Corporate social responsibility and corporate sustainability: Separate pasts, common futures. Organ. Environ. 2008, 21, 245-269. [CrossRef]

8. Bansal, P.; Song, H.C. Similar but not the same: Differentiating corporate sustainability from corporate responsibility. Acad. Manag. Ann. 2017, 11, 105-149. [CrossRef]

9. Aguilera, R.V.; Rupp, D.E.; Williams, C.A.; Ganapathi, J. Putting the S back in corporate social responsibility: A multilevel theory of social change in organizations. Acad. Manag. Rev. 2007, 32, 836-863. [CrossRef]

10. Mohrman, A.S.; Lawler, E.E., III. Designing organizations for sustainable effectiveness. A new paradigm for organizations and academic researchers. J. Organ. Eff. People Perform. 2014, 1, 14-34.

11. Carroll, A.B. Corporate Social Responsibility: Evolution of a Definitional Construct. Bus. Soc. 1999, 38, 268-295. [CrossRef]

12. Sheehy, B. Defining CSR: Problems and Solutions. J. Bus. Ethics 2015, 131, 625-648. [CrossRef]

13. Kuper, A. Redistributing Responsibilities-The UN Global Compact with Companies. In Real World Justice: Grounds, Principles, Human Rights, And Social Institutions; Follesdal, A., Pogges, T., Eds.; Springer Science \& Business Media: Berlin, Germany, 2005; pp. 359-380.

14. Rasche, A.; Waddock, S. Global Sustainability Governance and the UN Global Compact: A Rejoinder to Critics. J. Bus. Ethics 2014, 122, 209-216. [CrossRef]

15. Voegtlin, C.; Pless, N.M. Global Governance: CSR and the Role of the UN Global Compact. J. Bus. Ethics 2014, 122, 179-191. [CrossRef]

16. Sheehy, B. Conceptual and Institutional Interfaces among CSR, Corporate Law and the Problem of Social Costs. Va. Law Bus. J. 2017, 12, 95-145.

17. Sheehy, B. Private and Public Corporate Regulatory Systems: Does CSR Provide A Systemic Alternative To Public Law? Univ. Calif. Davis Bus. Law J. 2017, 17, 1-55.

18. Bebbington, K.J.; Gray, R.H. Sustainable development and accounting: Incentives and disincentives for the adoption of sustainability by transnational corporations. In Environmental Accounting and Sustainable Development; Hibbit, C., Blokdijk, H., Eds.; Limperg Instituut: Amsterdam, The Netherlands, 1996; pp. 107-151.

19. Matten, D.; Crane, A. Corporate Citizenship: Toward an Extended Theoretical Conceptualization. Acad. Manag. Rev. 2005, 30, 166-179. [CrossRef]

20. Crane, A.; Matten, D. Business Ethics: Managing Corporate Citizenship and Sustainability in the Age of Globalization; Oxford University Press: Oxford, UK, 2016.

21. Lawler, E.E., III; Conger, E.E. The sustainable effectiveness model: Moving corporations beyond the philanthropy paradigm. Organ. Dyn. 2015, 44, 97-103. [CrossRef]

22. Berle, A.J. Corporate Powers as Powers in Trust. Harv. Law Rev. 1931, 44, 1049. [CrossRef]

23. Dodd, E.M. For Whom are Corporate Managers Trustees? Harv. Law Rev. 1932, 45, 1145-1163. [CrossRef]

24. Sommer, A.A.J. Whom Should the Corporation Serve-The Berle-Dodd Debate Revisited Sixty Years Later. Del. J. Corp. Law 1991, 16,33 .

25. Bowen, H. Social Responsibilities of the Businessman; Harper \& Row: New York, NY, USA, 1953. 
26. Davis, K. Can business afford to ignore social responsibilities? Calif. Manag. Rev. 1960, 2, 70-76. [CrossRef]

27. Friedman, M. The Social Responsibility of Business is to Increase its Profits. N. Y. Times Mag. 1970, 32-33, $122-126$.

28. Carroll, A.B. The Pyramid of Social Corporate Responsibility. Bus. Horiz. 1991, 34, 39-48. [CrossRef]

29. Meseguer-Sánchez, V.; Gálvez-Sánchez, F.J.; López-Martínez, G.; Molina-Moreno, V. Corporate Social Responsibility and Sustainability. A Bibliometric Analysis of Their Interrelations. Sustainability 2021, 13, 1636. [CrossRef]

30. Sheehy, B.; Feaver, D. Re-Thinking Executive Control of and Accountability for the Agency. Osgoode Hall Law J. 2016, 54, 175-224. [CrossRef]

31. Feaver, D.; Sheehy, B. The Shifting Balance of Power in the Regulatory State: Structure, Strategy and the Division of Labour. J. Law Soc. 2014, 41, 203-226. [CrossRef]

32. Soule, S. Contention and Corporate Social Responsibility; Cambridge University Press: Cambridge, UK, 2009.

33. Mares, R. Global Corporate Social Responsibility, Human Rights and Law: An Interactive Regulatory. Transnatl. Leg. Theory 2010, 1, 221-285. [CrossRef]

34. Sheehy, B. Understanding CSR: An empirical study of private self-regulation. Monash Univ. Law Rev. 2012, 38, $103-127$.

35. Sheehy, B. CSR and Environmental Law. In The Oxford Handbook of Corporate Social Responsibility; Crane, A., Matten, D., McWilliams, A., Moon, J., Siegel, D.S., Eds.; OUP: Oxford, UK, 2019.

36. White, M.A. Sustainability: I know it when I see it. Ecol. Econ. 2013, 86, 213-217. [CrossRef]

37. Lozano, R. Envisioning sustainability three-dimensionally. J. Clean. Prod. 2008, 16, 1838-1846. [CrossRef]

38. Meadows, D.H.; Meadows, D.L.; Randers, J.; Behrens, W.W., III. The Limits to Growth (1972); Yale University Press: London, UK, 2013.

39. Carson, R. Silent Spring; Houghton Mifflin: New York, NY, USA, 1963.

40. Marshall, J.D.; Toffel, M.W. 2005 Framing the Elusive Concept of Sustainability: A Sustainability Hierarchy. Environ. Sci. Technol. 2005, 39, 673-682. [CrossRef] [PubMed]

41. Kuhlman, T.; Farrington, J. What is Sustainability? Sustainability 2010, 2, 3436-3448. [CrossRef]

42. Banon Gomis, A.J.; Guillen, M.; Hoffman, W.M.; McNulty, R.E. Rethinking the Concept of Sustainability. Bus. Soc. Rev. 2011, 116, 171-191. [CrossRef]

43. Baumgartner, R.J.; Rauter, R. Strategic perspectives of corporate sustainability management to develop a sustainable organization. J. Clean. Prod. 2017, 140, 81-92. [CrossRef]

44. World Commission on Environment and Development. Report of the World Commission on Environment and Development: Our Common Future; Oxford University Press: Oxford, UK, 1987.

45. Figgea, F.; Hahn, T. Sustainable Value Added-Measuring corporate contributions to sustainability beyond eco-efficiency. Ecol. Econ. 2004, 48, 173-187. [CrossRef]

46. Atkinson, G. Measuring corporate sustainability. J. Environ. Plan. Manag. 2000, 43, 235-252. [CrossRef]

47. Sachs, J.D. From millennium development goals to sustainable development goals. Lancet 2012, 379, 2206-2211. [CrossRef]

48. Griggs, D.; Stafford-Smith, M.; Gaffney, O.; Rockström, J.; Öhman, M.C.; Shyamsundar, P.; Steffen, W.; Glaser, G.; Kanie, N.; Noble, I. Sustainable development goals for people and planet. Nature 2013, 495, 305-307. [CrossRef]

49. Zerk, J. Multinationals and Corporate Responsibility: Limitations and Opportunities in International Law; Cambridge University Press: Cambridge, UK, 2006.

50. Bebbington, K.J.; Unerman, J. Achieving the United Nations Sustainable Development Goals: An enabling role for accounting research. Account. Audit. Account. J. 2018, 31, 2-24. [CrossRef]

51. Gallego-Sosa, C.; Gutiérrez-Fernández, M.; Fernández-Torres, Y.; Nevado-Gil, M.T. Corporate Social Responsibility in the European Banking Sector: Commitment to the 2030 Agenda and Its Relationship with Gender Diversity. Sustainability 2021, 13, 1731. [CrossRef]

52. Sprinks, J.; Woods, S.M.; Parkinson, S.; When, U.; Joyce, H.; Ceccaroni, L.; Gharesifard, M. Coordinator Perceptions When Assessing the Impact of Citizen Science towards Sustainable Development Goals. Sustainability 2021, 13, 2377. [CrossRef]

53. PWC. Make It Your Business: Engaging with the Sustainable Development Goals. 2015. Available online: https://www.pwc. com/gx/en/sustainability/SDG/SDG\%20Research_FINAL.pdf (accessed on 10 January 2019).

54. Hahn, T.; Figge, F. Beyond the bounded instrumentality in current corporate sustainability research: Toward an inclusive notion of profitability. J. Bus. Ethics 2011, 104, 325-345. [CrossRef]

55. Sheehy, B.; Feaver, D.P. Anglo-American Directors' Legal Duties and CSR: Prohibited, Permitted or Prescribed? Dalhous. Law J. 2014, 37, 347-395.

56. Sjåfjell, B.; Mähönen, J.; Novitz, T.; Gammage, C. Securing the Future of European Business: SMART Reform Proposals. 2020. Available online: https:/ / www.accountancyeurope.eu/wp-content/uploads/Draft-SMART-report-Business-4-March-2020.pdf (accessed on 2 April 2021).

57. Ruban, D.A.; Yashalova, N.N. Society and environment in value statements by hydrocarbon producers. Extr. Ind. Soc. 2021, 8,100873 .

58. Hoffman, A.J. From Heresy to Dogma: An Institutional History of Corporate Environmentalism; Stanford University Press: Palo Alto, CA, USA, 2001.

59. Dyllick, T.; Hockerts, K. Beyond the business case for corporate sustainability. Bus. Strat. Environ. 2002, 11, 130-141. [CrossRef] 
60. Amini, M.; Bienstock, C.C. Corporate sustainability: An integrative definition and framework to evaluate corporate practice and guide academic research. J. Clean. Prod. 2014, 76, 12-19. [CrossRef]

61. Vermeulen, W.J.V.; Witjes, S. On addressing the dual and embedded nature of business and the route towards corporate sustainability. J. Clean. Prod. 2016, 112, 2822-2832. [CrossRef]

62. Sjåfjell, B.; Richardson, B.J. Company Law and Sustainability; Cambridge University Press: Cambridge, UK, 2015.

63. Farneti, F. Il finalismo aziendale letto attraverso l'imperativo dello sviluppo sostenibile. In Studi di Diritto dell'Economia e dell'Impresa in Memoria di Antonio Cicognani; Stefanelli, A., Ed.; Cedam: Milan, Italy, 2012; pp. 187-200.

64. De Villiers, C.; Dumay, J.; Farneti, F. The EU Directive on Non-Financial and Diversity Information: A New Toothless Tiger Is Born? In Proceedings of the 41st Annual Congress of the European Accounting Association, Milan, Italy, 30 May-1 June 2018.

65. Mion, G.; Adaui, C.R.L. The Effect of Mandatory Publication of Nonfinancial Disclosure in Europe on Sustainability Reporting Quality: First Insights about Italian and German Companies. In Non-Financial Disclosure and Integrated Reporting: Practices and Critical Issues (Studies in Managerial and Financial Accounting, Volume 34); Songini, L., Pistoni, A., Baret, P., Kunc, M.H., Eds.; Emerald Publishing Limited: Bingley, UK, 2020; pp. 55-80.

66. Zumbansen, P. Transnational private regulatory governance: Ambiguities of public authority and private power. Law Contemp. Probl. 2013, 76, 117. [CrossRef]

67. Moon, J. The contribution of corporate social responsibility to sustainable development. Sustain. Dev. 2007, 15, 296-306. [CrossRef]

68. Sheehy, B. Corporations and Social Costs: The Wal-Mart Case Study. J. Law Com. 2004, 24, 1-55.

69. Ceesay, N.; Shubita, M.; Robertson, F. The Sustainability Reporting Practices in FTSE 100 Companies. In The Sustainability Debate (Critical Studies on Corporate Responsibility, Governance and Sustainability, Volume 14); Topić, M., Lodorfos, G., Eds.; Emerald Publishing Limited: Bingley, UK, 2021; pp. 77-100.

70. Shim, J.; Moon, J.; Seok Lee, W.; Chung, N. The Impact of CSR on Corporate Value of Restaurant Businesses Using Triple Bottom Line Theory. Sustainability 2021, 13, 2131. [CrossRef] 